\title{
Czech National Identity and the Elements Through Which is Constructed ${ }^{1}$
}

\author{
Veronika Kolaříková / e-mail: kolarikova.veronika@mail.muni.cz \\ Department of Social pedagogy, Faculty of Education, Masaryk University, Brno, Czech \\ Republic
}

Kolaříková, V. (2020). Czech National Identity and the Elements Through Which is Constructed. Czech-Polish Historical and Pedagogical Journal, 12/2, 66-96.

https://doi.org/10.5817/cphpj-2020-023

National identity is still one of the common components of identity of (post) modern people. The image of national identity is always country-specific, but individual national identities can share the same elements - for example they are associated with certain historical events related to national history, or are associated with national personalities. How the Crech national identity looks like may be by its owners more or less consciously formulated or implicit awareness. Some national and international research surveys are devoted to the topic of Crech national identity and bring partial findings concerning this phenomenon. However, a comprehensive overview of which specific elements constitute the Crech national identity and which thus contribute to its construction and reconstruction is missing in the literature. The aim of the study is therefore to find out and describe which elements constructing national identity are used in the concept of contemporary Crech national identity. The study will then use elements constructing the Czech national identity to create a coding key that, by categorizing

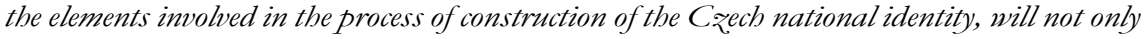
name and describe this identity, but also investigate it in more detail in future research surveys.

Key words: National identity; Crech nation; modernists; ethnosymbolists; coding key; historical memory; national stereotypes

\section{Introduction}

During the $19^{\text {th }}$ century, national identity became a natural component of identity of a modern man and still forms one of the basic components of the human identity, although the emphasis on it has changed over the years. On one hand, national identity and people's relationship to it are influenced by processes of globalization that can lead to a weakening of national identities and to the strengthening of the transnational identities. On the other hand in our times of postmodern risks and the times that are dealing with new social crises, we are witnessing new nationalist waves and movements that are still using national

1 The study was supported by the MUNI /A/1186/2017 project. 
identity as a legitimizing element. We live at a time when national identity carries different importance and meaning for different people, at a time when national identity is once again becoming an important issue not only for social scientists, but for the general public.

According to the Czech Population and Housing Census from the year 2011, the Czech Republic is characterized by national homogeneity with a dominant representation of Czech nationality ${ }^{2}$. According to the results of the international survey ISSP 32013 - National Identity III ${ }^{4}$, Czech national identity is the seventh most important group identity for Czechs, on the basis of which Czechs shape their personal identity. ${ }^{5}$ But what does the Czech identity actually mean? Czech nationality implies a specific form of identity that is discursively anchored and constantly constructed and reconstructed by a variety of elements, social practices, structures and functions.

To understand Czech national identity and its ideal-typical image we should define and describe the elements through which this identity is constructed, that is, those elements with which its form is discursively linked. In the literature there are partial descriptions of these elements. But comprehensive overview of elements by which is Czech national identity form is lacking in the literature. The aim of the study is therefore to identify and describe which elements constructing national identity are applied in the concept of contemporary Czech national identity and to anchor an ideally-typical image of Czech national identity. Therefore it will be necessary first to describe which elements are involved in the construction of national identities in general. In view of these issues, the structure of the study is as follows: in the first section, the study defines the concept of nation and national identity in terms of two key paradigms - modernism and ethnosymbolism. The second section deals with elements having an important role in the construction of the nation, respectively in forming a national identity. The third section is the key passage of the study and deals with the elements through which the Czech national identity is constructed. These elements are revealed in the study by studying and analysing of literature and research surveys, categorized and described. Following these categories of elements the coding key is created. The coding key can be understood as a categorization scheme that has been flipped into the methodological level, which can be further used in various research surveys.

2 Český statistický úřad. (2014). Národnostní struktura obyvatel. Český statistický úřad. p. 2. [cit. 15. 12. 2018]. Available from: https://www.czso.cz/documents/10180/20551765/17022314.pdf/d0d27736-ef15-4f4f-bf26-e7cb3770e187?version=1.0

3 International Social Survey Program (ISSP).

${ }^{4}$ Data analysis was performed by Vlachová, K., ed. (2015). Národní identity a identifikeace: Ceská republika - Visegrádská ćtyrkea - Evropská unie. Praha: Slon.

5 Respondents mentioned employee, family and age identities as the most important group identities. These were followed by an identity related to the part of the Czech Republic in which a one lives, followed by a gender identity and social-status identity. 


\section{Concept of National identity: modernism and ethnosymbolism}

National identity is one of many identities of (post) modern man and as such, it can be mutually combined with other identities (regional, ethnic, class, gender, etc.). National identity tells us and our surroundings who we are. Whatever this message is based on truth or fictional or an inaccurate stereotype, the image associated with a certain national identity has a discursive power. According to Smith ${ }^{6}$ national identity defines the position of man in the world, as it determines his or her belonging to a certain collective. It is a socially constructed group identity that determines the individual's belonging to a national group, which is usually given by cultural and political unity (objectively given factors). Members of one nation usually share a common national language, history, culture, traditions and an idea of the main national characteristics. They realize civil belonging to a given national state; they have a positive attitude to the country and feel solidarity with members of the nation (subjective factors). ${ }^{7}$

The concept of national identity may differ according to whom, when, and from what paradigmatic perspective works with this concept. It cannot be said that national identity has the same meaning at all times, in all societies and for all people. With this concept the study works like with the ideal Weber's type. Weber ${ }^{8}$ himself understood the concept of a nation as a hard-to-grasp concept that denotes certain group of people who have a specific sense of solidarity with each other. The study works with the concept of national identity as with a modern phenomenon that became typical for Europeans in $19^{\text {th }}$ century and over time it has evolved and spread to other areas, and in some form has survived to this day.

There are several perspectives through which we can look at national identity. Currently in scientific discourse dominates the modernist conception of the nation (e.g. Gellner). This concept understands nation as an unintended consequence of modern (European) society, in which at the turn of the $18^{\text {th }}$ and $19^{\text {th }}$ century the on-going structural changes caused the rise of nationalism. To the nationalism from which, according to Gellner ${ }^{9}$ has gradually emerged the need for a classification of people on the basis of belonging to the (same) nation. For Gellner, nationalism was the source of national identities that had strengthened in

${ }^{6}$ Hroch, M. (2009). Národy nejsou dílem náhody: Príciny a predpoklady utváreni moderních evropských národu. Praha: Sociologické nakladatelství. pp. 37-38.

7 Carey, S. (2002). Undivided Loyalties. Is National Identity an Obstacle to European Integration? European Union Politics, 3 (4), pp. 387-413.; Vlachová, K. - Ăeháková, B. (2004). Národ, národní identita a národní hrdost v Evropě. Sociologický ćasopis, 40(4), pp. 489-508.; Kubišová, Z. (2013). Národní identita: trvání a změna. In J. Šubrt et al., Soudobá sociologie $V$ (Teorie sociálni zmèny) (pp. 145-205). Praha: Karolinum

8 Hroch, M. (2006). Zmatky kolem nacionalismu. AntropoW ebrin, 1(2), pp. 49-65. P. 51.

9 Gellner, A. (1993). Národy a nacionalismus. Praha: Hř́ibal. 
modern society. But it is important to realize that nationalism, as Gellner ${ }^{10}$ himself pointed out, is not a once-for-all constructed and lasting phenomenon. However, nationalism has been changing and evolving, hand in hand with changes of the social structures and functions that have given to nationalism chance to arise.

Another important paradigm is ethnosymbolism (e.g. Smith, Hroch) whose proponents agree with modernists in a fact that nations are not immutable and always existing types of human community and that the advent of modern society has played a key role in the process of forming modern nations. Ethnosymbolists point out, however, that many modern nations were built on earlier existing ethnic ties and previous types of cultural and political communities, many elements of which, despite being transformed in modernity, have persisted. ${ }^{11}$ Smith therefore emphasizes the exploration of symbols, myths, memories, of the values, rituals and traditions that these communities were made up of and which they still supply today specificity (a certain form of language, religion, customs, institutions, etc.) and a generational feeling of continuity. ${ }^{12}$

The study works with both paradigms and tries to link their main ideas. The study draws from Gellner in the definition of the national phenomenon, which is from his perspective understood as a product of the changing structures of modernity. At the same time, study turns to the work of Hroch and Smith whose anchoring in the ethnosymbolistic paradigm is for defining the key elements involved in the construction of national identity important, as these authors focus on exploration of the elements through which collective ethnic identities and hence national identities are built and maintained.

\section{Elements Concerning the Construction of Nation and National Identity}

There are a number of elements through which national identity is constructed. These elements, respectively their categories, as we can see in the text below, often overlap and relate to each other. Still, it is useful to include them in these categories for clarity and other analytical work.

The first category consists of (1) historical memory. An important role in shaping national identity always had national bistory and national myths. They gave the community a feeling of continuity, thus not only describing its existence, but also legitimizing it. National myth defines $\mathrm{Hroch}^{13}$ as a story that was more or

10 Gellner, E. (2003). Nacionalismus. Brno: Centrum pro studium demokracie a kultury.

${ }^{11}$ Kubišová, Z. (2013). Národní identita: trvání a změna. In J. Šubrt et al., Soudobá sociologie V (Teorie sociální zmèny) (pp. 145-205). Praha: Karolinum.; Hroch, M. (2009). Národy nejsou dílem náhody: Príciny a predpoklady utváreni moderních evropských národì. Praha: Sociologické nakladatelství.

12 Smith, A. D. (2009). Ethno-symbolism and Nationalism: A cultural approach. London: Routledge.

13 Hroch, M. (2009). Národy nejsou dílem náhody: Př́ciny a prédpoklady utvárení moderních evropských národĩ. Praha: Sociologické nakladatelství, p. 190. 
less purposefully integrated into the co-ordinates on which there was founded the idea of common faith that unites members of nation as well as the idea of a shared national past. Construction of national myths and history in the past was based on oral narratives and written pre-modern historical traditions, i. e. on stories that were part of a living collective memory. It gradually associated with the invention of writing and the gradual written record of important events. In modern society, the history of the nation was one of the fundamental arguments used in the efforts to national mobilization and civic education, so in the justification of the ethnic group's right to national existence. ${ }^{14}$ National history and myths have become an important part of the forming national identity and nations as well.

In a collectively shared historical memory that helps to understand a given collective identity and its history as a continuous reality, according to Smith ${ }^{15}$ are contained mainly myths about common origin (these help perceive community in which one lives as an extended family), myths about liberation and myths about "chosenness" (about the specificity and peculiarity of the nation and its mission), notions of common destiny (associated with victims which members of the nation must bring for their good), memories of heroic deeds (often of victorious battles) and treatises of "real" major events (so-called ethno-history), linked to the "memories" of the golden age of the national community (political or military glory, period of plenty, time of significant architectural buildings, works of art, science or religion, the period of national virtues and ideals, etc.) and with narrations about the great deeds of the ancestors and remembrance of the great personalities after which the current members of the group have inherited the "common blood" and who are part of the roots ${ }^{16}$ of the nation, and hence the idea of "who we are" and what historical events we should be proud of.

${ }^{14}$ Hroch, M. (2009). Národy nejsou dílem náhody: Príciny a predpoklady utvárení moderních evropských národĩ. Praha: Sociologické nakladatelství, p. 168.

15 Kubišová, Z. (2013). Národní identita: trvání a změna. In J. Šubrt et al., Soudobá sociologie $V$ (Teorie sociální zmèny) (pp. 145-205). Praha: Karolinum.; cf. Smith, A. D. (2009). Ethnosymbolism and Nationalism: A cultural approach. London: Routledge.; Hroch, M. (2009). Národy nejsou dílem nábody: Pričiny a predpoklady utváreni moderních evropských národü. Praha: Sociologické nakladatelství.

16 Cultural roots (often mythical and rebellious) have become not only a tool for constructing the common identity of community members, but also a means of celebrating its culture. The roots were at the beginning of the community cult that established that the traditional values of the community must be protected. The emphasis on people's roots began to forming the period of romanticism, that is, in a period in which modernity slowly began to expand with its mobility and the old hierarchical order slowly broke-up. Compared to the earlier Enlightenment vision of the universality of people, romanticism put emphasis on cultural specificity, which he tied to the need for profound emotions (cf. Gellner, E. (2003). Nacionalismus. Brno: Centrum pro studium demokracie a kultury and Gellner, E. (2005). Jazyk a samota: Wittgenstein, Malinowski a habsburské dilema. Brno: Centrum pro studium demokracie a kultury.). 
The nation's historical memory and its above-mentioned elements are reflected in so-called sites of memory. Sites of memory can be understood as concrete but also abstract places in which it was incarnated historical memory. These are a kind of specially designed places for remembering. It doesn't have to these are only places of a material nature (monument, cemetery, museum, pilgrimage site, extinct villages, etc.), but also the symbolic and functional elements presented by the various media and forms in which are reflecting socially relevant topics on various issues and past events that have become a symbol of the community. Such as a stories of major battles or personalities, nation-specific artefacts such as trabant or prefab house, a history book, a family chronicle, a funeral ceremony, a pilgrimage, etc. ${ }^{17}$ Sites of memory are with categories of historical memory closely intertwine and deepen its theoretical background and at the same time correspond with other elements that construct national identity and complement them with other elements, such as historical artefacts, writings and specific places associated with historical events, memories, and their reminders.

The notion of sites of memory was elaborated by Nora, ${ }^{18}$ according to whom the time of origin of nations was also time of perception of notions of memory and history; the time of separation of these two phenomena. The time when people began to turn to the past as something past and ended with what it is necessary to know and worship; they began to turn to the future as to the something that have to be prepared; and that all in the spirit of national rhetoric. Sites of memory have become memory relics that must be preserved and reminded because they no longer exist in the currently lived (spontaneous) memory of people. Therefore, it must be maintained artificially (through festivals and anniversaries, memorials, cemeteries, museums, archives, alliances) otherwise there would be a risk of their disappearance. Sites of memory are used to symbolize ours past and its constructed meaning for our present. Nora speaks about the materialization of memory and about some for (post)modern society typical will to preserve this memory.

In addition to historical memory, the collective (national) identity is further shaped by (2) characteristic cultural features of groups. These are group-specific values - sacrament values, heroism, honour, justice, democracy, etc., norms, canonical texts, symbols and sacred objects, food, dressing, emblems, etc. Important

${ }^{17}$ Nora, P. (1998). Mezi pamětí a historií. In Francouzský ústav pro výzkum ve společenských vědách, Antologie francouzskéch společenských véd: politika paméti (pp. 7-31). Praha: CEFRES.; Šubrt, J. - Pfeiferová, Š. (2010). Kolektivní pamět’ jako předmět historickosociologického bádání. Historická sociologie, 1(2010), pp. 9-29.; Havlůjová, H., Najbert, J. et al. (2014). Pamét’ a projektové vyucování v dějepise. Praha: Ústav pro studium totalitních režimů.

18 Nora, P. (1998). Mezi pamětí a historií. In Francouzský ústav pro výzkum ve společenských vědách, Antologie francousskéch společenských věd: politika pamèti (pp. 7-31). Praha: CEFRES. 
role have also shared traditions, festive feasts, rituals, and other specific activities (e.g. religious practices) that shape and strengthen the collective identity of the group, sense of reciprocity and unity. They also participate in defining themselves towards other groups. An important component is the language spoken by members of groups through which they usually distinguish themselves from other groups. ${ }^{19}$

Another category of elements involved in the process of forming the national identity consists of (3) national stereotypes through which members of a nation create categorization of themselves and the outside world. These stereotypes are based on autostereotypes (ideas about ourselves) and heterostereotypes (ideas of others). Autostereotypes and heterostereotypes are involved in differentiation and exclusion processes, which are according to Smith ${ }^{20}$ involved in shaping the boundaries between communities. People who are beyond a certain community often give rise to suspicion or a sense of threat in the people of that community. The form of these stereotypes is very closely related to the context of the time and socio-political conditions of their origin and period of further functioning. It often takes the form of more permanent a character that is transmitted in more or less the same form across generations. ${ }^{21}$

Previous processes are associated with (4) the process of naming populations, when the name symbolically represents a cultural group and its identity and thus participates not only in the categorization of people, but also to strengthen the sense of belonging of the group members. By naming the national community as "we" the group defines itself and at the same time differentiates itself from other groups ("them"). Members of a foreign nation can be perceived not only as different, but also as ancient enemies, or as our neighbours who are similar to us ("Other Slavs"). ${ }^{22}$

An important element of the construction of nation and national identity, which is closely linked to (5) the territory of a nation and its specific nature, such as the type of landscape whose shape is closely woven into the historical myths and memory of the community, is (6) a nation state on whose importance is

19 Kubišová, Z. (2013). Národní identita: trvání a změna. In J. Šubrt et al., Soudobá sociologie $V$ (Teorie sociální żmèny) (pp. 145-205). Praha: Karolinum, pp. 153-195; Smith, A. D. (2009). Ethno-symbolism and Nationalism: A cultural approach. London: Routledge.; Hroch, M. (2009). Národy nejsou dílem nábody: Priciny a prédpoklady utváreni modernich evropských národi. Praha: Sociologické nakladatelství.

20 Smith, A. D. (2009). Ethno-symbolism and Nationalism: A cultural approach. London: Routledge.

21 Hroch, M. (2009). Národy nejsou dílem náhody: Príciny a préedpoklady utvárení moderních evropských národui. Praha: Sociologické nakladatelství.

22 Hroch, M. (2009). Národy nejsou dílem nábody: Př́ciny a prédpoklady utvárení moderních evropských národi. Praha: Sociologické nakladatelství.; Smith, A. D. (2009). Ethnosymbolism and Nationalism: A cultural approach. London: Routledge. 
emphasized especially by modernists. According to Gellner, ${ }^{23}$ nationalism is tied with the idea that the state is a universal human institution that delimits a national group from others groups; institutions headed by members of the nation and space where all members share the same national culture. Next to its territory, the nation state is connected with two other important variables. First one is a law system that is involved in the process of delineation national borders. Law system is part of a high culture and according to Smith, ${ }^{24}$ it participates in creating a sense of unity and mutual solidarity among the members of the nation sharing this legal system. The second area consists of state symbols, which according to $\mathrm{Hroch}^{25}$ at the time of nation building, helped spread national identity and inspired trust in the nation among people. These symbols made it possible to represent the nation abroad and strengthen citizen's confidence in the state. The nation-state today plays a major role in the process of maintaining a nation and its identity, because government institutions by their very existence and performance contribute both to maintain the organizational framework of the national community and to ensure the conditions necessary for the functioning of national public culture. ${ }^{26}$

For the process of forming national identities is important also (7) the attachment of members of an ethnic or national group to a given territory „homeland“, „home“ - territory that has always been inhabited by a particular community. The attachment of members of the nation to its territory it is usually accompanied by an emotional bond and a feeling of love for the homeland, the socalled patriotism ${ }^{27}$. Positive emotions associated with own nation are often accompanied by neutral or negative emotions in relation to foreign nations. ${ }^{28}$

23 Gellner, E. (2003). Nacionalismus. Brno: Centrum pro studium demokracie a kultury.

24 Smith, A. D. (2009). Ethno-symbolism and Nationalism: A cultural approach. London: Routledge.

25 Hroch, M. (2009). Národy nejsou dílem nábody: Príciny a prédpoklady utvárení moderních evropských národi. Praha: Sociologické nakladatelství, p. 238.

26 Kubišová, Z. (2013). Národní identita: trvání a změna. In J. Šubrt et al., Soudobá sociologie $V$ (Teorie sociální żmèny) (pp. 145-205). Praha: Karolinum. p. 190.

27 Gellner (2003) considers national feeling, i. e. love for the homeland, its culture and people, as a social construct that arose in modernity along with the forming nationalism. By this statement, Gellner does not want to question the authenticity and the sincerity of this feeling. It merely points out that national sentiment is not historically or geographically universal phenomenon. This is a phenomenon for which specific social conditions were necessary to allow love for the nation, and thus the very awareness of its existence.

28 Kubišová, Z. (2013). Národní identita: trvání a změna. In J. Šubrt et al., Soudobá sociologie V (Teorie sociální żmèny) (pp. 145-205). Praha: Karolinum.; Smith, A. D. (2009). Ethnosymbolism and Nationalism: A cultural approach. London: Routledge.; Hroch, M. (2009). Národy nejsou dílem náhody: Príciny a prédpoklady utváreni moderních evropských národu. Praha: Sociologické nakladatelství.; Gellner, E. (2003). Nacionalismus. Brno: Centrum pro studium demokracie a kultury. 


\section{Elements that Construct Czech National Identity}

It is a difficult task to describe the concept of Czech national identity. The image of Czech national identity is still to some extent constructed around the "traditional" concept of the forming process of Czech nation that itself has been subjected to reinterpretations and criticism many times (remember, for example, the dispute over sense of Czech history, which took place between Masaryk, Pekař and other thinkers at the turn of $19^{\text {th }}$ and $20^{\text {th }}$ centuries). But it is not possible to assume that the concept of Czechism has not changed since then and was passing as a constant. Yet many persistent elements of the traditional concept of Czech national identity could be traced up to this day. It is possible to ask how are these elements present in institutionalized practices involved in the process of construction of Czech national identity and the extent to which they are internalized by individual social actors. There should be taken into account further development of Czech national identity, including all historical-sociocultural context of contemporary Czech society. The questions, we can ask, may be related to the effort to find out which new (say postmodern) elements are in the context of understanding and construction national identities now emerging and what their position alongside traditional elements is. What is the role of multicultural discourse and other phenomena in them?

Another difficulty of this effort is the fact that the author giving the interpretation becomes the designer of the nation and its concept of national identity himself/herself. As noted by the important anthropologist Holý, ${ }^{29}$ history is not a straightforward story of all past events, but rather a story of those who are perceived by contemporaries as important and involved in today's form of reality: What we consider to be Czech history is a construction that allows us to understand things in the sense that we are what we are because this or that happened in our past. It is a construction that is an integral part of discourse that constantly constructs and reconstructs Czech identity. As the author of this study, I am aware of this fact, and in describing the Czech national identity I attempt to clarify primarily those elements which, according to a cross-section of the professional literature and research investigations carried out, still play a dominant role in the awareness of the Czechs and are still involved in the construction of the Czech national identity.

\section{Categorization scheme of elements constructing Czech national identity}

The study above focused on defining general elements that have an important role in shaping national identity. We are now specifying the categorization scheme related to national identity and, using an analytical reading of literature and

29 Holý, L. (2010). Malý český člověke a skevélý český národ: Národní identita a postkomunistická transformace spolećnosti. Praha: Sociologické nakladatelství. p. 17. 
research ${ }^{30}$, we will fill the resulting categories, thereby creating a categorisation scheme for elements constructing Czech identity. The coding key thus generated can be further verified and subsequently used in new research investigations, for which it creates not only a theoretical background but, above all, an analytical framework. In doing so, the coding key works with Czech national identity as an ideal type and this itself becomes a sort of ideally-typical model, representing in contemporary discourse dominating concept of Czech national identity. In practice, this means that the study does not assume that such a conceived national identity is universally valid for all Czechs, nor that its described elements occur in all people, at all times and in strictly established form. The presented model of Czech national identity may vary and may also contain other elements in reality and therefore some categories also remain open to possible further additions.

The coding key works with five main categories that are further developed into sub-categories. The first code key category Czechs and their roots correspond to the original general category Historic memory (sites of memory). This general category was broken down into two sub-categories at the stage of concretisation, and therefore the category Czechs and their shared memories of major historical events and personalities is also included. In the category Czechs and their roots, due to the thematic grouping, the original general category Naming of population is also included in the form of the subcategory Czechs (population name). General categories Characteristic cultural features and National stereotypes have been merged into the third category with the name Czechs and their characteristic cultural features. The fourth category of coding key consists of the category Czechs and national territories, Nation state. This category arose from the merging of two general categories (Territory of nation and the National state) that cover each other under the conditions of the Czech Republic. There is also the issue of important (symbolic) sites in the Czech Republic and we can monitor the blending

30 This study is the type of review study that processes research data presented in research reports and expert literature. It works with the results of the Centre for Public Opinion Research of the Sociological Institute of the Czech Republic, with research findings presented by the Czech Statistical Office or the Sociological Institute of the AV of the Czech Republic. The research findings presented across the years also bring the book Historical consciousness of the inhabitants of the Czech Republic through the perspective of sociological research (Šubrt, J. - Vinopal, J., et al. (2013). Historické védomi obyvatel české republiky perspektivon sociologickébo výzkumu. Praha: Karolinum.). International Eurobarometer research projects, the International Social Survey Programme (ISSP), whose results are described in book Vlachová, K., ed. (2015). Národní identity a identifikace: Ceská republika - Visegrádská ctyrkea - Evropská unie. Praha: Slon.; and the European Values Study (EVS), whose results are presented by Rabušic, L. - Chromková Manea, B. (2018). Hodnoty a postoje v Ceské republice 1991-2017: Pramenná publikace European Values Study. Brno: Masarykova univerzita.; are also an important source of data. Alongside research investigations, the study works with the professional literature of the authors of Thunder, Rak, Holý, Klepetko, Kohák, Koukolík and others. 
of the category with the topic of sites of memory. To some extent, the last category is tied to this topic. The fifth category Other elements and memory sites related to Czech national identity contain elements that were not possible or desirable to be placed in previous categories because of their specificity. Here we can find subcategories such as Czechs and sport as an important element of national identity, Czechs and religion, and Czechs and other artefacts of a symbolic nature relating to Czech national identity. This category remains open to further potential additions.

\subsection{Czechs and their roots}

\section{- Czechs (population name)}

The naming of the population is instrumental in defining the identity of the community and in establishing the boundaries between it and a population named differently. The name of the national group covers the group and helps people think of it as about a certain category. The origin of the term Czech is interpreted in several ways. Czech etymological Dictionary ${ }^{31}$ lists as the most likely option an interpretation derived from the basis of a head-to-head reference to the meaning of family, human. The second possible option is to derive from the concepts of chic, garlic, but also "beat", then Bohemia would mean "warrior".

\section{- Ethnicity and myth of common origin - Slavs}

Since the time of the Czech National Revival, most Czechs have shared the idea of common Slavic roots as well as the similarity of the cultures of Slavic nations, among which Czechs rank themselves. ${ }^{32}$ The Czechs share not only similar language and traditions with other Slavic nations. According to respondents they share also similar mentality, appearance and historical experience. Slovak, Polish and partly Russian cultures are seen as the Czech culture closest to it. According to the primordialist understanding of the nation prevailing in Europe of the 19 ${ }^{\text {th }}$ century, as well as the Czech historiographical tradition, Czech history began with the arrival of Slavic (Czech) tribes in Bohemia. From the falsified manuscripts Královédvorský and Zelenohorský, national ideology took over the reference to the grandfather Čech (“Czech”), prince Krok, Přemysl Oráč of the Oracle and other figures. ${ }^{33}$ The Slavic nation was seen as the great and powerful nation of Europe, whose primetime and glory were brought to the attention of Dobrovský, Jungmann and other Czech patriots.

But later, Czech history only became regarded as national from the time of the creation of the Principality of Bohemia in the $10^{\text {th }}$ century. The Greater Moravian

31 Rejzek, J. (2012). Ceský etymologický slovník. Praha: Leda. p. 111.

32 Šubrt, J. - Vinopal, J., et al. (2013). Historické védomi obyvatel české republiky perspektivon sociologického výzkumu. Praha: Karolinum. pp. 194-198.

33 Rak, J. (1994). Bývali Čechové... (české historické mýty a stereotypy). Jinočany: H \& H. 
Empire is considered "the first historically documented state in Central Europe"34 and as such Great Moravia (and with it its princes or Byzantine scholars Cyril and Methodius) is remembered as an important part of Czech national existence. Since its time, Czech history has been seen as a constant development of a political unit, first a principality and, since the early $13^{\text {th }}$ century, a kingdom that has never faded in the eyes of national revivalists, though its sovereignty was weakened after 1620 . The concept was one of the reasons why historical arguments were formulated in terms of "historical rights" became the common denominator of Czech political requirements in the late $19^{\text {th }}$ century. ${ }^{35}$

Apart from the idea of who the Czechs are and what all Slavs have in common, the definition towards other nations is also a part of national identity. In the context of Czech identity, it is primarily about definition towards the Germans. According to Hroch and Malečková36 before 1860 , Czech historians did not explore foreign nations. They paid attention only to the role and influence of the Germans. At the same time, from Palackýs work, the national revivalists chose mainly moments describing Czech-German rivalry and expansion, while frequent instances of peaceful coexistence and cultural transmission were marginalised. ${ }^{37}$ Czechs embodied the principle of freedom and democracy in this relationship, while Germans perceived as a symbol of the "hereditary enemy" represented the principle of authority and oppression. Although the concept did not find unreserved approval among later generations of historians, it survived as a stereotype in Czech political culture until the $20^{\text {th }}$ century and remains, to some extent, to this day.

\section{- Czech language}

Since the Middle Ages, both Bohemia and Moravia have been inhabited by most Czech-speaking residents and a minority who speak German. ${ }^{38}$ The written Czech language was established during the $14^{\text {th }}$ century and remained the official language of the administration until the $17^{\text {th }}$ century. But after 1627, German became a dominating official language due to the new constitution. By the end of the $18^{\text {th }}$ century, "our countries were already part of a large German cultural region. Polis of the Czech countries - that is, a civic component of their population, which at the time meant nobility, a higher clergy, educators and more

34 Holý, L. (2010). Malý český člověke a skevélý český národ: Národní identita a postkomunistická transformace společnosti. Praha: Sociologické nakladatelství. p. 97.

35 Hroch, M. - Malečková, J. (1999). The construction of Czech national history. Historein, 1(1999), pp. 103-112.

36 Ibid.

37 Rak, J. (1994). Bývali Cechové... (české historické mýty a stereotypy). Jinočany: H \& H.

38 Hroch, M. (2004). From ethnic group toward the modern nation: the Czech case. Nations and Nationalism, 10(1/2), pp. 95-107. 
affluent townsfolk - felt quite of course, unproblematic ally German." 39 It is assumed there has been a degree of ethnic identity among residents that, with some exceptions, did not include xenophobia or spontaneous patriotic enthusiasm. A social structure based on social status was crucial. According to Gellner, ${ }^{40}$ traditional society was strictly hierarchically organised. People demonstrated their status through a different status culture, not ethnicity. Cultural diversity has been functional in traditional society and utterly unquestioned by anything. The difference in language became visible only in a modernizing society in which migrant peasants were exposed to different experiences in the cities with regard to the language they spoke. The German peasant joined the company with an official language similar to the local dialect. A Czech peasant joined society with an official language that he did not understand, and that made social upheaval more difficult for him. Nor was the accessibility of education, after the Teresian reforms, equally available to everyone. While primary schools remained under church control and taught local languages, most colleges were secularized and Latin was replaced by German as a language of instruction.

The inadequate status of Czech has become a symbol of the obstacle to the vision of a society of equal citizens that has formed into a modernizing Enlightenment society. New intellectuals felt a sense of injustice that led to a desire to fight for linguistic equality. But it was not easy to elevate the Czech language to the official language. Czech was the language of villagers at the end of the $18^{\text {th }}$ century, not the language of science, art, bureaucracy or nobility that the Czech nation lacked. The Czech revivals thus came from the people's backgrounds. Rather than warlords or politicians, it involved new young scholars (such as philosophers and artists) who, in the process of finding their place in society and their identities, began to turn precisely to the identity of the national, which was represented in the Czech language. ${ }^{41}$ This led to a linguistic and ethnic-cultural concept of a nation prevailing in Bohemia, unlike in the states of Western Europe, in which the identity of the nation with the state was not self-evident. ${ }^{42}$ The nation was seen as an entity mirrored in a common language, history, traditions and cultural belonging. First and foremost, the revivalist sought to strengthen the sense of Czech belonging and rebuild statehood within the federated Habsburg

39 Kohák, E. (2009). Domov a dálava: Kulturni totožnost a obecné lidství v českém myšlení. Praha: Filozofia. P. 19.

40 Gellner, E. (2003). Nacionalismus. Brno: Centrum pro studium demokracie a kultury.

${ }^{41}$ Kohák, E. (2009). Domov a dálava: Kulturni totožnost a obecné lidství v českém myšlení. Praha: Filozofia.; Hroch, M. (2004). From ethnic group toward the modern nation: the Czech case. Nations and Nationalism, 10(1/2), pp. 95-107.

42 Rak, J. (1994). Bývali Céchové... (české historické mýty a stereotypy). Jinočany: H \& H.; Kohák, E. (2009). Domov a dálava: Kulturni totožnost a obecné lidství v českém myšlení. Praha: Filozofia.; Holý, L. (2010). Malý český clověk a skevélý český národ: Národni identita a postkomunistická transformace spolećnosti. Praha: Sociologické nakladatelství. 
monarchy, and only then could they think about building an independent Czech state. In doing so, he was subsequently supposed to defend Czech national interests, that is to say, protect Czech language and culture.

Czech remains an essential symbol of Czech to this day. In ISSP 2013 international research ${ }^{43}$, respondents identified the ability to speak Czech as the most important symbol of Czech. Even in 2017, $91 \%$ of Czech respondents of European Values Study ${ }^{44}$ agreed that real Czech speaks Czech language. Yet since the Czech National Movement, a gradual change in the concept of Czech national identity can be seen. Czech identity is now more closely associated with the territory of the Czech Republic than before. According to Vlachová and Ăeháková, ${ }^{45}$ Czechs commonly identify with their nation-state, which forms the most dominant part of their territorial identity. Also findings of Šubrt and Vinopal ${ }^{46}$ emphasise that contemporary Czechs ,perceive themselves, just as other European nations, as both a state and a cultural nation. The real Czech man and Czech woman is the one who can speak Czech, feels to be Czech, has Czech citizenship, lives on Czech territory most of his/her life and was born on the Czech territory. Czech national identity is linked in particular to language, a sense of belonging to the Czechs, to citizenship and to life on Czech territory." The incorporation of the state dimension into the Czech identity may already be linked to several years of experience of the existence of its own nation-state, which is already self-evident to most of the young Czechs.

\subsection{Czechs and their shared memories of major historical events and personalities}

\section{- Czechs and their memories of the Golden Age}

What events the Czechs perceive as the most important period in Czech history greatly affects the shape of their concept of national identity. Interpretations of historical events and associated persons can transform over the years, in the context of the optics of the present as well as of who interprets these historical events and with what objectives they do so. Most typically, we follow this transformation in ways of viewing the Hussite Wars and the character of Jan $\check{Z}$ ižka, whose image oscillates between a national hero and a bloodthirsty robber.

43 Vlachová, K., ed. (2015). Národní identity a identifikace: Česká republika - Visegrádská ćtyrkea - Evropská unie. Praha: Slon. P. 137.

44 Rabušic, L. - Chromková Manea, B. (2018). Hodnoty a postoje v Céské republice 1991-2017: Pramenná publikace European Values Study. Brno: Masarykova univerzita. p. 238.

45 Vlachová, K. - Ăeháková, B. (2004). Národ, národní identita a národní hrdost v Evropě. Sociologický ćasopis, 40(4), pp. 489-508.

46 Šubrt, J. - Vinopal, J., et al. (2013). Historické védomi obyvatel Ceské republiky perspektivou sociologického výzkumu. Praha: Karolinum. p. 176. 
An overview of historical events that the Czechs consider significant is offered by Šubrt and Vinopal, ${ }^{47}$ through which the research presented dates back to 1946. The authors tried to infer the dominants of Czech national memory from the research submitted, and summed up that by 1989, there were themes of Hussitism, the Czechoslovak Republic, and Charles IV's reign in people's imaginations as of the brightest periods of Czech history. These themes, according to the authors, point to the fact that "the public tend to judge history through the prism of a particular period context and picks up from it primarily phenomena or events that symbolize some current ideal or values to which the public is fixated at that time." 48

The 2010 research investigation produced similar results. ${ }^{49} 90 \%$ of respondents described the time of Charles IV's reign as the economic success, which is usually referred to as the "father of the nation." His era is seen as a time of flowering for Czech countries and their international importance. During the National Revival, it was highlighted as a time of education, advanced culture, and period of the power status. The paradox is that Charles IV's personality as a representative of the golden age of a given nation was worshipped not only by the Czechs, but during the Middle Ages and the early New Ages also by the French and the Germans. ${ }^{50}$

The period of Charles IV's reign was followed by the period of the Great Moravian Empire; the period of the Kings of Premysl family; the periods of Maria Theresa and Joseph II's reign; and the period of the First Republic. ${ }^{51}$ Times of the First Czechoslovak Republic, according to Kohák, ${ }^{52}$ still gives the Czechs the idea of a golden age. Which is confirmed by opinion polls from 2018, when $66 \%$ of Czechs view the period positively, and $68 \%$ of respondents thinking that the formation of the first Czechoslovakia contributed to the survival of the Czech nation. ${ }^{53}$ The ideal of the First Republic is linked to Masaryk's democratic and

${ }_{47}$ Šubrt, J. - Vinopal, J., et al. (2013). Historické védomi obyvatel české republiky perspektivou sociologického výzkumu. Praha: Karolinum.

48 Šubrt, J. - Vinopal, J., et al. (2013). Historické védomi obyvatel české republiky perspektivou sociologického výzkumu. Praha: Karolinum. p. 107.

${ }^{49}$ Šubrt, J. - Vinopal, J., et al. (2013). Historické védomi obyvatel české republiky perspektivou sociologického výzkumu. Praha: Karolinum. pp. 107-117.

50 Hroch, M. (2009). Národy nejsou dílem náhody: Príciny a predpoklady utvárení moderních evropských národũ. Praha: Sociologické nakladatelství.

51 Šubrt, J. - Vinopal, J., et al. (2013). Historické védomi obyvatel české republiky perspektivou sociologického výzkumu. Praha: Karolinum. pp. 107-117.

52 Kohák, E. (2009). Domov a dálava: Kulturní totožnost a obecné lidství v českém myšlení. Praha: Filozofia. P. 197.

53 Tisková zpráva Občané o osobnostech, obdobích a událostech česko-slovenské historie od v₹niku CSR po současnost - brezen 2018. (2018). Sociologický ústav AV ČR: Centrum pro výzkum veřejného mínění. [cit. 28. 6. 2019]. Available from: https://cvvm.soc.cas.cz/media/c om_form2content/documents/c2/a4607/f9/pd180509.pdf 
progressive conception of the history of the Czechoslovak nation. The celebrations of the First Republic that held in the Czech Republic in 2018 reflects the idealization and celebration of that time. But in fact, the First Republic was not the ideal democratic state that many would claim to be. Consider, for example, the 1927 law on "wandering gypsies and persons living the Gypsy way," 54 which, as a democratic one, we certainly cannot talk about as it was involved in discriminating against both nomadic and non-nomadic Roma and people "living in gypsy way." People classified into this category were identified as delinquents who seemed to need to be normalized, which ultimately meant separating them from society, assigning them special legitimacy cards, prohibiting them from entering certain places, and, over time, with other expanding legislation during the Protectorate send them into labour camps, etc.

The Czechoslovak Republic's creation period is also more complex because the Czechoslovakia with its internal cultural diversity did not respond to the idea of folk nationalism about a one-nation state. Rather than being a independent nation, it was an artificially created multinational and multilingual state formation, that was resembled to a miniature of the Austro-Hungarian Empire; nation where national ideology disregarded the needs of Slovaks or other minorities, and the German population perceived in the prism of the old Austrian oppressors. ${ }^{55}$

The Hussite period was in a given research identified as "the golden age" by only $36 \%$ of respondents and $2 \%$ of respondents perceived the time as an era of decline. ${ }^{56}$ This fact shows how varied the concept of the period has been in the past. According to Hroch and Malečková ${ }^{57}$ as well as according to Kohák, ${ }^{58}$ it was Palacký who, with the help of Jirásek and Aleš, proclaimed Hussite Revolution as a period of golden ages. The Czech National Revival highlighted the Hussite Revolution as a time of national awareness and rally of the population, symbolizing the struggles against an external enemy for freedom. ${ }^{59}$ In fact, the reason for the Hussite revolution was not a national revival, but a struggle for faith in salvation that the church could not convey to the poor faithful believers. The

54 More about this law in Fafejta, M. (2007). Fafejta „Cikáni“ - rasa, nebo způsob života. Sociálni studia, 4 (2007), pp. 93-111.

55 Kohák, E. (2009). Domov a dálava: Kulturni totožnost a obecné lidství v českém myšlení. Praha: Filozofia. p. 91.; Koukolík, F. (2015). Ceši: Pročjsme kdo jsme - a jak dál. Praha: Galén. p. 17.; Baar, V. (2002). Národy na prahu 21. století. Emancipace nebo nacionalismus? Ostrava: Tilia.

56 Šubrt, J. -Vinopal, J., et al. (2013). Historické védomi obyvatel české republiky perspektivou sociologického výzkumu. Praha: Karolinum. pp. 107-117.

57 Hroch, M. - Malečková, J. (1999). The construction of Czech national history. Historein, 1(1999), pp. 103-112.

58 Kohák, E. (2009). Domov a dálava: Kulturní totožnost a obecné lidstvi v českém myšlení. Praha: Filozofia.

59 Rak, J. (1994). Bývali Cechové... (české historické mýty a stereotypy). Jinočany: H \& H. 
expansion of the Czech language was an accompanying phenomenon of these events rather than their deliberate goal. Later, Communist ideology also highlighted the Hussite Revolution. By the end of the $20^{\text {th }}$ century, the Hussitism had been rowed back, and the role of the Slavic priests Cyril and Methodius and St. Vaclav got to the forefront of the interest.

There is a need to add the Velvet Revolution of November 1989 into the socalled "List of Events". This was positively assessed by $72 \%$ of respondents from the Sociological Institute of Sciences of the Czech Academy of Sciences opinion survey in 2018, which looked at how people in both the Czech and Slovak Republics rate the various historical events of these countries from the beginning of the $20^{\text {th }}$ century to the present. ${ }^{60}$

\section{- Czechs and memories of the days of decline}

In 2010, the perception of decline times among Czech respondents was similar to previous years. As the period of decline, $86 \%$ of respondents identified the period of protectorate of Bohemia and Moravia. This period is linked with a negative perception of the time of the Munich Agreement. ${ }^{61}$ Even in 2018, a majority of respondents $(66 \%)$ agreed on the concept of the Munich Agreement as a result of the failure of our Western allies. ${ }^{62}$ According to Kohák ${ }^{63}$ the Munich Agreement forms a myth that the Czechs have not coped with yet, and which forms "perhaps the most desperate, devastating and demoralising moment in our history since the White Mountain." The events involved in capitulating to Germany are seen as something Czechs should be ashamed of. Events persist in shared memory as a betrayal of allies that, along with the surrender of President Beneš, made it impossible for the determined citizens of Czechoslovakia to resist Hitler's expansion. Šubrt and Vinopal ${ }^{64}$ mention the interesting fact that "the assessment of the period as a decline does not mean that it could not have provided a significant positive impetus in the construction of historical

${ }^{60}$ Tisková apráva Osudové osmičky v historickém védomi ceské a slovenské verejnosti: události, obdobi, osobnosti. (2018). Sociologický ústav AV ČR: Centrum pro výzkum veřejného mínění. [cit. 28. 6. 2019]. Available from: https://cvvm.soc.cas.cz/media/com_form2content/ documents/c2/a4645/f9/pd180612.pdf

61 Šubrt, J. - Vinopal, J., et al. (2013). Historické védomi obyvatel české republiky perspektivou sociologického výzkumu. Praha: Karolinum. pp. 100-109.

62 Tisková apráva Občané o osobnostech, obdobich a událostech česko-slovenské historie od v₹niku Č́R po současnost - brezen 2018. (2018). Sociologický ústav AV ČR: Centrum pro výzkum veřejného mínění. [cit. 28. 6. 2019]. Available from: https://cvvm.soc.cas.cz/media/c om_form2content/documents/c2/a4607/f9/pd180509.pdf

63 Kohák, E. (2009). Domov a dálava: Kulturni totožnost a obecné lidství v českém myšlení. Praha: Filozofia. p. 206.

64 Šubrt, J. - Vinopal, J., et al. (2013). Historické védomi obyvatel české republiky perspektivou sociologickébo vý̃kumu. Praha: Karolinum. p. 136. 
consciousness or national identity." It was the period of occupation that the respondents were described as the period in which the Czechs behaved most bravely.

There is also a prism of defeat in the Battle of the White Mountain, which ended in 1620 the era of the Hussite Revolution. According to Kohák ${ }^{65}$ defeat brought an end to religious pluralism as well as disintegration of for that time existing sense of belonging of Czech rural people. The power monopoly of both the emperor and the Catholic Church has intensified. The folk nationalists at the time of the First Republic's formation, perceived these events as a period when the Czech nation narrowly escaped its own doom and as a period followed by a time of "darkness" and decline, i.e. time of humiliation of the Czech nation, its recatholization and germanization, a time of foreign domination. The national revivalists, meanwhile, overlooked the fact that the Czech inhabitants of the monarchy in the 18th century were all Catholics with no doubt about their loyalty to the emperor. Anti-Habsburg sentiments did not begin to grow until the 19th century, when the stereotype of the Habsburgs as enemies of the Czechs and their national interests also invaded. ${ }^{66}$

Scientists are also looking at a period of normalisation (prism of communism). The establishment of the Communist regime in February 1948 is viewed negatively by around a third of today's Czechs, who also call the occupation of Czechoslovakia by Warsaw Pact troops in August 1968 a negative event in Czech history. ${ }^{67}$ Subrt and Vinopal ${ }^{68}$ pointed to one interesting fact - in 2009 , the research participants of "Aktér" research did not assess the state of Czech society before and after November fundamentally differently, although the current regime was generally rated better than the previous one (the one $79 \%$ of respondents said was undesirable). As a justification, authors offered the fact that many of the reforms and targets taken after the November events are not seen as successful by the Czech public - according to many Czechs, there has been no expected settlement with Western countries in terms of economic or living standards of the population. People in 2009 also felt anxious with under fulfilled

65 Kohák, E. (2009). Domov a dálava: Kulturni totožnost a obecné lidství v českém myšlení. Praha: Filozofia. pp. 68-69.

${ }^{66}$ Kohák, E. (2009). Domov a dálava: Kulturní totožnost a obecné lidství v českém myšlení. Praha: Filozofia. p. 184.; Hroch, M. - Malečková, J. (1999). The construction of Czech national history. Historein, 1(1999), pp. 103-112.; Rak, J. (1994). Bývali Céchové... (české historické mýty a stereotypy). Jinočany: $\mathrm{H} \& \mathrm{H}$.

67 Tisková apráva Občané o osobnostech, obdobich a událostech česko-slovenské historie od v₹niku CSR po současnost - brezen 2018. (2018). Sociologický ústav AV ČR: Centrum pro výzkum veřejného mínění. [cit. 28. 6. 2019]. Available from: https://cvvm.soc.cas.cz/media/c om_form2content/documents/c2/a4607/f9/pd180509.pdf

68 Šubrt, J. - Vinopal, J., et al. (2013). Historické védomi obyvatel české republiky perspektivon sociologického výzkumu. Praha: Karolinum. pp. 142-143. 
values regarding social security, a sense of security, interpersonal relationships and old-age security.

\section{- Important personalities of Czech history}

Among the important personalities of Czech history, according to Hroch and Malečková, ${ }^{69}$ are those who have earned the spread of Czech culture, the defence of national interests, the political consolidation of the Czech state or those who have contributed to Czech glory abroad. Šubrt and Vinopal ${ }^{70}$ bring an overview of the transformation of the ranking of the best rated persons in Czech history and show that since 1946 are repeating figures such as Charles IV, Hus, Komenský, Palacký, St. Vaclav, Masaryk and, in modern history president Havel. Masaryk, as a positively regarded political figure in Czech history, also prevailed as part of the 2018 assessment of respondents in public opinion research, where $84 \%$ of Czechs rated him positively. ${ }^{71}$ In the same research, Czechs also positively rated the character of Palach $(67 \%)$ and Havel $(66 \%)$. Also artists (Mácha, Mucha, Destinová, Dvořák, Smetana, Kundera, Kupka, Forman, etc.), inventors (Wichterle) and athletes (Jágr), often appear in the consciousness of Czechs. ${ }^{72}$ The interesting thing is that among the notable Czechs, people also rank fictional characters such as Švejk, or Cimrman. The character of Maria Theresa and Joseph II is also important characters. Although these are not Czech figures, because their origin is Habsburg, these personalities are perceived by Czechs as important figures for the Czech nation. The reason for this, according to Hroch, ${ }^{73}$ are the reforms, which were instrumental in transforming the shape of society at the time and its life, and which (even if unintentionally) contributed to shaping a new national identity.

\subsection{Czechs and their distinctive cultural features}

\section{- Czechs and their autostereotypes - i.e. alleged national characteristics}

The concept of a nation is linked to collective self-conception, to the notion of a form of national character, i.e. the notion of defined personality characteristics

${ }^{69}$ Hroch, M. - Malečková, J. (1999). The construction of Czech national history. Historein, 1(1999), pp. 103-112.

70 Šubrt, J. - Vinopal, J., et al. (2013). Historické védomí obyvatel české republiky perspektivon sociologickébo výzkumu. Praha: Karolinum. pp. 115-119.

71 Tisková zpráva Obíané o osobnostech, obdobich a událostech česko-slovenské historie od v₹niku CSR po současnost - brezen 2018. (2018). Sociologický ústav AV ČR: Centrum pro výzkum veřejného mínění. [cit. 28. 6. 2019]. Available from: https://cvvm.soc.cas.cz/media/c om_form2content/documents/c2/a4607/f9/pd180509.pdf

72 Klepetko, R. (2014). Současná role národní identity, aneb proč (ne)stavíme národní památníky. Kulturni studia, 1 (2014), pp. 64-79.

73 Hroch, M. (2004). From ethnic group toward the modern nation: the Czech case. Nations and Nationalism, 10(1/2), pp. 95-107. 
common to members of a culture and which are further linked to stereotypes associated with the notion of the social, physical and mental characteristics of the nation members. National character is a social construct that is constructed by social actors and subsequently accepted by them as an objective model of reality. In the process of construction of a national character, there are more involved social prejudices, historical experiences and historical myths and stereotypes. ${ }^{74}$

The Czechs describe as positive Czech qualities the sense of humour, skill and diligence (so-called golden Czech hands and traditional crafts associated with them), friendliness, musicality, the democracy of a nation, when democratic tradition is legitimized by claims referring to the notion that Czechoslovakia was the only democratic country in the interwar period Central Europe. They also mention an advanced high culture reflected in works of art, in the revivalist efforts even during the reign of Charles IV, intelligence (the so-called common sense) and with it associated behaving as a well-known Czech literary character named Švejk. ${ }^{75}$ Czechs perceive Švejk as an intelligent person who has his stupidity only pretended. ${ }^{76} \mathrm{On}$ the contrary, foolishness is a characteristic that has always been attributed to the foreign nations by Czechs. ${ }^{77}$

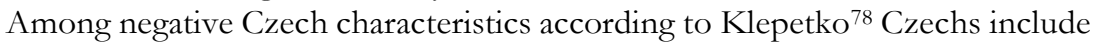
envy, laziness, thefts and dissatisfaction. According to Prokop, ${ }^{79}$ Czechs are said to

${ }^{74}$ Koukolík, F. (2015). Češi: Proč jsme kedo jsme - a jak dál. Praha: Galén.; Labischová, D. (2013). Češi, Slováci a jejich sousedství: Identita - stereotyp - historické vědomí. CIVILIA - odborná revue pro didaktiku společenských véd, 4(2), pp. 46-54.

75 Klepetko, R. (2014). Současná role národní identity, aneb proč (ne)stavíme národní památníky. Kulturní studia, 1 (2014), pp. 64-79.; Labischová, D. (2013). Češi, Slováci a jejich sousedství: Identita - stereotyp - historické vědomí. CIVILIA - odborná revue pro didaktiku společenských věd, 4(2), pp. 46-54.; Holý, L. (2010). Malý český clověk a skvélý český národ: Národni identita a postkomunistická transformace společnosti. Praha: Sociologické nakladatelství.

76 Holý dealt with the Czech national identity of people during the normalization period and after the collapse of the communist regime. According to Holý, L. (2010). Malý ceský clovék a skevély český národ: Národni identita a postkomunistická transformace spolećnosti. Praha: Sociologické nakladatelství, pp. 68-69) “The Czech nation survived three centuries of oppression not thanks to its heroes, but thanks to small Czech people who made the nation. The other side of the conceptualization of a typical member of the Czech nation as a small Czech man is the construction of the Czech nation as a nation of simple, ordinary and nothing special people." According to Holý, this description of Czechism also corresponds to Švejk.

77 Holý, L. (2010). Malý český člověke a skevèlý český národ: Národní identita a postkomunistickéa transformace společnosti. Praha: Sociologické nakladatelství, p. 78.

78 Klepetko, R. (2014). Současná role národní identity, aneb proč (ne)stavíme národní památníky. Kulturni studia, 1 (2014), pp. 64-79. p. 72.

79 Prokop, D. (2015b). Kapitola 36: Mýtus stěžovaného národa, aneb co si Češi nalhávají o Češích. In P. Lyons, R. Kindlerová eds., 47 odstínu české společnosti (pp. 228-232). Praha: Sociologický ústav AV ČR. 
be endlessly complaining nation, but recent research did not confirm this. Nor was the tendency towards excessive envy. Yet envy as autostereotype of the Czechs is also mentioned by Labischová, ${ }^{80}$ who in the list of Czechs autostereotypes complements cowardice, inconsistency and inability to resist at the time of oppression. Also Holý ${ }^{81}$ draws attention to envy as an autostereotype of Czech people and complements intolerance, setting small goals, conformity and the related orientation of man and his activities to a narrow circle of family, friends and colleagues. Everything beyond these limits is perceived by a "small Czech" as potentially threatening and untrustworthy. Similarly, in 2015, according to Prokop, ${ }^{82}$ the fear of foreigners was apparent among Czechs, manifesting itself more strongly in the young generation and in group of people who do not have personal experience with members of other nationalities. As another negative feature of Czechs, according to Labischová, ${ }^{83}$ there is mentioned alcoholism. According to The Organisation for Economic Co-operation and Development, ${ }^{84}$ the Czech Republic is one of the countries with the highest alcohol consumption. Alcohol is associated with high tolerance for drinking and the Czechs are called a nation of beer-drinkers. According to Vinopal ${ }^{85}$ beer has a specific position in Czech culture since the 15th century. During the Czech National Revival the pub was one of the few public places for speaking in Czech and for discussing revival efforts. Pubs thus became the centre of the development of the Czech social and cultural life and beer became a constitutive element of patriotic ideology.

How the Czechs perceive the stereotype of a typical Czech depends, to some extent, not only on a discursive basis and the prevalence of the respondent itself, but also on how deeply is man identified with its own nationality. People little identified with Czech identity perceive a typical Czech as more neurotic, less conscientious, less welcoming, less extraverted and less open to new experiences than people more identified with Czech identity. Those perceive a typical Czech more in a range of neutral characteristics, rather than in some positive characteristics and the opposite to those who attribute people identified with Czech less often. ${ }^{86}$

80 Labischová, D. (2013). Češi, Slováci a jejich sousedství: Identita - stereotyp - historické vědomí. CIVILIA - odborná revue pro didaktiku společenských věd, 4(2), pp. 46-54.

81 Holý, L. (2010). Malý český člověke a skevèý český národ: Národní identita a postkomunistická transformace společnosti. Praha: Sociologické nakladatelství.

82 Prokop, D. (2015a). Kapitola 35: Proč se bojíme cizincư? In P. Lyons, R. Kindlerová eds., 47 odstinu české společnosti (pp. 224-227). Praha: Sociologický ústav AV ČR.

83 Labischová, D. (2013). Češi, Slováci a jejich sousedství: Identita - stereotyp - historické vědomí. CIVILIA - odborná revue pro didaktiku společenských věd, 4(2), pp. 46-54.

84 OECD. (2018). Alcohol consumption (indicator). [cit. 9. 10. 2018]. Available from: https://data.oecd.org/healthrisk/alcohol-consumption.htm

85 Vinopal, J. (2005). Fenomén pivního patriotismu v české společnosti. Naše společnost, 3(2), s. 31-37.

86 Vlachová, K., ed. (2015). Národní identity a identifikace: Ceská republika - Visegrádská čtyrkaa - Evropská unie. Praha: Slon. p. 46. 


\section{- Czech national traditions - intangible cultural heritage}

National traditions play a similar role to society as national myths, but they are not the same things. Unlike myth, tradition is claiming continuity with the past, it is not a memory of the past; tradition considers itself as a more or less organic sequel. ${ }^{87}$ The concept of tradition refers to the cultural heritage passed down through generations per generation. ${ }^{88}$ We rank traditions, folk customs and rituals to the intangible cultural heritage, which is a dynamic part of the culture being selected by a social group in order to preserve it for future generations. It consists of oral traditions and expressions including language, performing arts, social practices, ceremonies and festive events, knowledge and experience related to nature and space, skills associated with traditional crafts. ${ }^{89}$

Czech intangible cultural heritage is reflected in forms of folk culture, which according to Kourili ${ }^{90}$ as a symbol of folklorization of the people occupies an important position among self-legitimizing narratives of the nation-state. Folklore manifestations are associated with a specific public events and festivities. Folk traditions are usually related to individual seasons that have always determined the natural course of everyday life. There are four seasons in the Czech Republic. Spring is typically associated with Easter or "burning witches", summer with harvesting and pilgrimages, autumn is tied with autumn harvest, feasts, St. Wenceslas, All Souls' Day and winter with St. Nicholas, Christmas, New Year, Groundhog Day etc. Within the framework of specific folk traditions, it is possible to perceive regional conditionality that suggests that national identity is closely connected with regional identities and that these identities can influence and complement each other.

The verbal folklore (fairy tales, songs, folk theatre) was considered as a symbol of Czechism in the $19^{\text {th }}$ century. ${ }^{91}$ This folklore was associated with a romanticizing view and was often reflected in the works of Erben, Čelakovský, Šafař́k and other authors. Fairy tales remain part of the Czech self-concept till this day. A Czech fairy tale is considered as something traditional and basically makes up the product of Czech traditional craft. Czech fairy-tales have a typical fairy-tale character, which is "Foolish" Honza. Foolish Honza was originally the actor of the

87 Hroch, M. (2009). Národy nejsou dílem náhody: Príciny a predpoklady utvárení moderních evropských národu. Praha: Sociologické nakladatelství, p. 191.

88 Šubrt, J. - Vinopal, J., et al. (2013). Historické védomí obyvatel české republiky perspektivon sociologického výzkumu. Praha: Karolinum, p. 22.

89 Janeček, P. (2015). Evropská etnologie a koncept nehmotného kulturního dědictví. Národopisná revue, 25(3), pp. 273-282, p. 275.

90 Kouřil, P. (2004). Displacement a pojem tradiční lidové kultury. Sociální studia, 1(2), pp. 43-56. P. 43.

91 Pavlicová, M. (2015). Folklor a folklorismus v historické a sociální perspektivě. In A. Kř́žová, M. Pavlicová a M. Válka, Lidové tradice jako součást kulturního dédictví (pp. 165-204). Brno: Masarykova univerzita. 
tales with no good ending, and Honza usually was there and also often remained the fool. However, fairy tales, with the contribution of writer Božena Němcová, gradually transformed, got a good ending and their content gained an educational character - encouraged to diligence, hard work, and kindness. In the $20^{\text {th }}$ century, Honza's positive image stabilized. Foolish Honza is nowadays perceived as stupid only seemingly. Stupidity is attributed to him by his surroundings like his stigma. But at the right moment, Honza always proves his cleverness, honesty and courage. Honza can also be described as the owner of the common sense, a fearless or confused survivor. It is true that across different period Honza as a folk character remained a certain representation of cultural stereotypes of the nation, especially its rural population..$^{92}$

\section{- Czechs and material cultural heritage}

In the $19^{\text {th }}$ century, material culture phenomena began to be used to construct national identity, which typically include folk clothing, which was created in contrast to non-folk clothing, that is, the garments of members of the nobility, the rich bourgeoisie, the church or the army. With national identity architecture is also related. In the second half of the 19th century, the village house was promoted to one of the symbols of nationally understood national culture and as part of the cultural heritage began to be documented, studied and became a model and a source in drawing up the Czech idea National Building Style, which was to become an expression of national identity. ${ }^{93}$ The life of the rural population and its culture has become a symbol of Czechism. The villager was perceived as a preserver of the Czech language and thus as a "true Czech." All attention was dedicated to the traditional and pre-industrialized ways of life of the peasants who were idealized. Topics related to negative features of rural life (lack of hygiene, alcoholism) as well as the fact that the villagers did not deal with the national question as much as they did revivalists in cities, has been delayed. ${ }^{94}$

The material cultural heritage can also include important architectural buildings, works of art, including applied arts, which are often part of museum collections, literary works, inventions or dishes, etc. Traditional dishes are mainly associated with specific days of the year, holidays and important events

${ }^{92}$ Kubů, E. - Šouša, J. (2017). Pohádkový Honza. Zamyšlení nad jedním z mentalitních symbolů české vesnice druhé poloviny 19. a prvních decennií 20. století. Historická sociologie, 1(2017), pp. 127-135.

93 Válka, M. (2015). Lidový dům a národní kulturní dědictví. In A. Křřžová, M. Pavlicová a M. Válka, Lidové tradice jako součást kulturního dédictví (s. 89-164). Brno: Masarykova univerzita. pp. 93-94.

94 Rak, J. (1994). Bývali Cechové... (české historické mýty a stereotypy). Jinočany: H \& H.; Pavlicová, M. (2015). Folklor a folklorismus v historické a sociální perspektivě. In A. Kř́žzová, M. Pavlicová a M. Válka, Lidové tradice jako součást kulturního dédictví (pp. 165-204). Brno: Masarykova univerzita. 
(Christmas, Easter, weddings, etc.). As the traditional food of Czechs it is considered pork roast with dumplings and cabbage, sirloin and pork cutlet. Also stew, dumplings, stuffed buns, potato pancake, roast goose or duck. Czech cuisine is considered to be rich and tasty by Czechs. ${ }^{95}$

\section{- Czechs and their specific values and attitudes}

Basic human values are usually stable over time, and as Lyons ${ }^{96}$ points out, their characteristics tend to have a strong national basis and regional cultural values are not as import as the national ones in many countries. The question if fundamental values of Czechs are unique, Lyons put himself. According to him the survey showed that collectivist and conservative values are combined by Czechs. On the one hand, the Czechs recognize the value of social justice and help others, and on the other hand they also have conservative attitudes based on respect for traditions.

A specific value or rather an attitude may be pride in one's own nation, the socalled patriotism and feeling of belonging to other members of the nation. According to Šubrt and Vinopal, ${ }^{97}$ contemporary Czechs do not address the issue of national identity too much and they do not belong to the most proud nations. Yet pride to be Czech feel $85 \%$ of respondents. According to the results of the survey European Values Study from 2017 only $28 \%$ of men are very proud of being Czech citizens, $51 \%$ are quite proud of it. Very proud of being Czech citizens are $37 \%$ of women and $49 \%$ of them are quite proud. ${ }^{98}$ The Czechs are mostly proud of history, literature, art, science, technique and sports achievements. ${ }^{99} \mathrm{On}$ the contrary, they are not very proud of the functioning of Czech democracy; they are not pleased with the small political influence of the Czech Republic in the world, functioning of the economy and social security. Subrt and Vinopal ${ }^{100}$ explain that little pride on the performance of the state is typical for nations that have undergone a long period of illegitimacy an authoritarian or totalitarian system of governance.

95 Seidlová, A. (2003). Česká tradiční kuchyně. Naše společnost, 1(3-4), pp. 5-11.

${ }^{96}$ Lyons, P. (2015a). Kapitola 28: Je možné měřit lidské hodnoty? A jsou lidské hodnoty Čechů jedinečné? In P. Lyons, R. Kindlerová eds., 47 odstínů české společnosti (pp. 173-1179). Praha: Sociologický ústav AV ČR, p. 179.

97 Šubrt, J. - Vinopal, J., et al. (2013). Historické védomi obyvatel České republiky perspektivou sociologického výzkumu. Praha: Karolinum, p. 177.

98 Rabušic, L. - Chromková Manea, B. (2018). Hodnoty a postoje v Céské republice 1991-2017: Pramenná publikace European V alues Study. Brno: Masarykova univerzita, p. 228.

${ }^{99}$ Klepetko, R. (2014). Současná role národní identity, aneb proč (ne)stavíme národní památníky. Kulturní studia, 1 (2014), pp. 64-79.; Šubrt, J. - Vinopal, J., et al. (2013). Historické védomí obyvatel Ceské republiky perspektivou sociologického výžkumu. Praha: Karolinum.

100 Šubrt, J., Vinopal, J., et al. (2013). Historické védomi obyvatel Ceské republiky perspektivon sociologickébo výzkumu. Praha: Karolinum, p. 178. 


\subsection{Czechs and National territories, National state}

Within the subcategory Czech language, the study has already outlined that the concept of Czech identity among Czechs historically and culturally based primarily on the ethnic-cultural model of the nation's construction, which emphasized the connection of Czechs in the area of common culture (including language and traditions) and history. However, the concept of the homeland as a specific national territory has been gradually integrated into the concept and remains part of it to this day. This is evidenced, for example, by the findings of the European Values Study from 2017 according to which 73 \% of Czech respondents agreed on that in order to be a true Czech, it is important that a person was born in the Czech Republic and has a Czech origin, i.e. has ancestors from the Czech Republic $-70 \%$ of respondents agreed on this. ${ }^{101}$ This is also related to the fact that Czech citizenship is in the Czech Republic acquired by the principle of ius sanguinis ("the law of blood"), i.e. in situation when his/her parents are Czech nationals. At the same time respondents (94\%) agreed that true Czech respects the political institutions and laws of the Czech Republic.

\section{- Important places of the Czech Republic}

The Czech nation state and its geographical location are associated with important places, which are perceived by Czechs as symbols of national history as well as places representing Czech nation. Among the important places people rank Prague, which was already perceived as a symbol of power of the country and its "mother" during the time of Czechoslovakia. As an important symbol of Czechness there are perceived also Hradčany, Wenceslas Square, Prague Castle, Charles University and Karlštejn castle. Outside Prague then people consider Ăíp mountain to be important places, places associated with World War II such as towns Terezín and Lidice, Tábor, pilgrimage site Velehrad and Vítkov Hill, Olomouc and Kroměřižz, places connected with Czech natives, Václav Havel Airport and others. ${ }^{102}$

National monuments and sculptures are connected with important places and personalities (e.g. sculptures of Masaryk), which have not only artistic and aesthetic character. According to Koselleck, ${ }^{103}$ the aim of memorials is not just

101 Rabušic, L. - Chromková Manea, B. (2018). Hodnoty a postoje v Céské republice 1991-2017: Pramenná publikace European V alues Study. Brno: Masarykova univerzita. pp. 235-237.

102 Šubrt, Vinopal et al., 2013, pp. 124-126; Klepetko, R. (2014). Současná role národní identity, aneb proč (ne)stavíme národní památníky. Kulturní studia, 1 (2014), pp. 64-79.; Holý, L. (2010). Malý český člověk a skevélý český národ: Národni identita a postkomunistická transformace společnosti. Praha: Sociologické nakladatelství.

${ }^{103}$ Koselleck, R. (2002). War Memorials: Identity Formation of the Survivors. In R. Koselleck. The Practice of Conceptual History: Timing History, Spacing Concepts (pp. 285-326). Stanford: Stanford University Press. 
about trying to keep in people's minds memories of the death people, but above all symbolize identity (based on symbols of honesty, victory, heroism, martyrdom, etc.) that people can acquire and share. Monuments have an (self) identification function ant their main aim is to promote especially national identity. An interesting feature of the Czech environment is the fact that, there is only few memorials about victorious battles or famous warlords (except Žižka). The Czechs are more concerned with symbolizing the suffering and depicting martyrs (Hus, St. Wenceslas) than with celebrating victory and its representatives. ${ }^{104}$

\section{- Fauna and flora of the Czech Republic}

The nation is symbolized by a certain type of landscape, which can be called a national country. Given the nature of the national landscape, members of a nation can define their homeland, which can be in the Czech context reflected not only in the description of the beauty of local nature (often rural), but also in the absence of sea and beaches, high mountains, glaciers, deserts, etc. On the contrary, the Czech Republic has forests rich in mushrooms and this can lead along with certain socio-cultural conditions to develop the phenomenon of mushroom hunting, which is typical for Czechs. Another typical Czech phenomenon is spending time at second houses, which is usually put into context with the era of socialism. But Schindler-Wisten ${ }^{105}$ points out that modern beginnings of this phenomenon we can see in Czech history two decades earlier. Residents of cities spent their free time in cottages also because of other circumstances and motives than simply because of escaping from political life. This is evidenced by the never-ending interest in this type of leisure activities after 1989.

At the centre of attention there is also the "possession" of mineral resources, whose essential component in the Czech Republic is coal production, which still affects national identity (and regional identity) to this day. Not only the specific flora but also the fauna is associated with the national landscape. Thanks rugged relief and the varied landscape character of the Czech Republic, its fauna is rich; 42 thousand species of known animals here. ${ }^{106}$

\section{- Czech state symbols}

The official state symbolism of the Czech Republic is defined by the Czech Constitution, which says that among the Czechs National symbols there belong big and small national emblem, national colours, national flag, flag of the President,

${ }^{104}$ Holý, L. (2010). Malý český člověk a skevělý ceské národ: Národní identita a postkomunistické transformace společnosti. Praha: Sociologické nakladatelství.

105 Schindler-Wisten, P. (2017). O chalupách a lidech: Chalupárství v českých zemích v obdobi tz̃v. normalizace a transformace. Praha: Karolinum, p. 10.

106 Anděra, M. - Sovák, J. (2018). Atlas fauny Ceské republiky. Praha: Academia. 
state seal and national anthem. The function of these symbols is identification and representative and these symbols contribute to the reminiscence of the historical continuity of the country. ${ }^{107}$ The transformation of these symbols is related to specific historical events and periods that are part of the Czech history. For national flags, according to Eriksen ${ }^{108}$ it is typical that they are ambiguous, respectively multivalent, to prove to create a symbolic bond and a sense of community among people who are very different and have different interests. People can interpret the flag in different ways according to theirs personal experience. Through the simple national symbol people can feel national belonging. In this way, state rituals can actually act as symbols that lead to collective action.

\section{- Political institutions and laws of the Czech Republic}

The Czech Republic is a unitary parliamentary republic in which the legislative body forms a bicameral parliament consisting of the Chamber of Deputies and the Senate, the executive body of power is the government of the Czech Republic and the head of state is the President. The constitution of the Czech Republic forms the basis of the legal system adopted in 1993.

\section{- The Czech currency - Czech crown}

In the context of national identity, the currency used in a given society also plays a role that helps to define "us" towards nations with a different currency. The Czech crown was officially introduced on 1 January 1993 as the Czech currency. This new currency became a symbol not only of the Czech Republic, but also symbol of events connected with the separation of the Czech and Slovak Republics. No less important there are also motives found on banknotes that represent important personalities for the nation, historical scenes and symbols. In the construction of identities, the Euro can play a specific role, since it represents not only the currency used in the country, but also country's membership of the European Union, whose members have adopted the euro as their own currency.

\section{- Czechs and their relationship to Europe and the European Union}

The Czech Republic has been a part of the European Union since 2004. Since then, the relationship of Czechs has gone through some developments, and over the years the proportion of people who think the European Union has too much influence on people's lives in the Czech Republic has risen. ${ }^{109}$ Public Opinion

107 Sedláček, P. (2007). Symboly republikey. Praha: Úřad vlády České republiky.

108 Eriksen, T. H. (2008). Sociálni kulturni antropologie: Prábuæenství, národnostni př̌slušnost, rituál. Praha: Portál, pp. 272-273.

109 Šubrt, J. - Vinopal, J., et al. (2013). Historické védomí obyvatel Céské republiky perspektivon sociologického výzkumu. Praha: Karolinum. 
Research conducted by the Institute of Sociology of the Academy of Sciences of the Czech Republic in April $2019^{110}$ brings results slightly more positive. According to research, people's satisfaction with EU membership is highest since 2010, although it has not changed much compared to last year. Satisfaction with Czech membership in the European Union, is expressed by less than two fifths of Czech citizens $(37 \%)$ and over a quarter (26\%) is dissatisfied. According to the latest European research Eurobarometer published in summer 2018, 111 however, the Czechs belong to nations that tend to distrust the European Union alongside Greeks and Englishmen. Moreover, the majority of Czechs (67\%) think that the Czech has little influence among Member States and its voice is usually unheard. $65 \%$ of Czech citizens even think that European Union decisions are not in the interest of the Czech Republic. ${ }^{112}$

According to the results of the Eurobarometer $59 \%$ of Czechs feel like members of the European Union and $40 \%$ of them do not feel to be citizens of European Union. For the Czechs, the European Union means above all the possibility of free travel, study and employment opportunities, but along with this, bureaucracy is considered as synonym for the European Union. The lack of control of external borders is also perceived by Czechs in the EU context as insufficient. On the other hand, public opinion survey from April 2019 states that people are satisfied with European integration in the field of defence, as well as ecology. At the same time, according to the Eurobarometer, the EU is not seen by most Czechs as a source of economic prosperity or social protection. Unlike other EU members, the Czechs do not identify the European Union too much with the euro, peace or cultural diversity.

\subsection{Other elements and sites of memory related to Czech national identity}

\section{- Czechs and sport as an important element of the national identity}

Sport events are an important part of not only Czech national identity. In Czech Republic are to the process of construction of Czech identity involved for example,

110 Tisková apráva Názory verejnosti na členstvi České republiky v Evropské unii - duben 2019. (2019). Sociologický ústav AV ČR: Centrum pro výzkum veřejného mínění. [cit. 27. 6. 2019]. Available from: https://cvvm.soc.cas.cz/media/com_form2content/documents/c2/a4920/f9/ pm190502.pdf

111 Standard Eurobarometer 89 - Spring 2018. (2018). Public opinion in the European Union: First results. European Union: Kantar Public Brussels on behalf of TNS opinion \& social. [cit. 27. 12. 2018]. Available from: http://ec.europa.eu/commfrontoffice/publicopinion/ index.cfm/Survey/getSurveyDetail/instruments/STANDARD/surveyKy/2180

112 Tisková apráva Hodnocení evropské integrace - duben 2019. (2019). Sociologický ústav AV ČR: Centrum pro výzkum veřejného mínění. [cit. 27. 6. 2019]. Available from: https://cvvm. soc.cas.cz/media/com_form2content/documents/c2/a4928/f9/pm190528.pdf 
in the hockey victory in the Nagano Winter Olympics in 1988, or celebrating the victorious Olympian Ester Ledecká, who became a media-sought celebrity after her success in the 2018 Winter Olympics. Eriksen ${ }^{113}$ considers sport as an important ritual of modern times that can play a role in the process of expressing national identity. Klepetko ${ }^{114}$ agrees with this, because his questionnaire survey showed that some Czechs appreciate collective companionship during sporting matches and they are proud of sporting achievements during the Olympic Games, in hockey or tennis. Among the important Czechs, then, respondents appointed important Czech athletes (Jágr, Zátopek and others).

\section{- Czechs and religion}

The Czech Republic is perceived by us and in the world as one of Europe's most atheist states. Most Czechs (more than 80 \%) say they do not believe in God, which according to Lyons ${ }^{115}$ does not mean they do not believe in anything else. 4 out of 10 Czechs believe in "something." It is not necessarily a Christian or Catholic faith, many believers do not associate their faith with any church, yet religion plays an important part for them. Also Laudátová and Vido ${ }^{116}$ point out that the fact that even though many Czech residents do not subscribe to any religion, it may not mean that Czechs are disbelieving or atheistic nation. Religious affiliation does not have to overlap with religious beliefs necessarily. More people from the older generation than young people subscribe to religion in the Czech Republic. This is also corresponded to by the fact that over the years it has been possible to see a decline in people claiming to faith. The total number of believers in the population fell from $43 \%$ in 1991 and 1999 to $31 \%$ in 2008 and proportionately to this, in the society there were added more convinced atheists, that is, people rejecting any concept of God.

Nevertheless, the Czech identity is linked to religion, largely to Christianity to some extent, because the Czech traditions and culture are also linked to it. Christianity was in the year 2013 an important part of the Czech identity for $29 \%$ of respondents, mostly those who subscribe to the Christian faith themselves and those living in settlements with a population of less than 100,000 inhabitants. On the contrary, Christianity is not linked to Czech identity by young people under 35. ${ }^{117}$

${ }^{113}$ Eriksen, T. H. (2008). Sociálni kulturni antropologie: Př́buzenství, národnostni př̌slušnost, rituál. Praha: Portál, pp. 273-275.

114 Klepetko, R. (2014). Současná role národní identity, aneb proč (ne)stavíme národní památníky. Kulturni studia, 1 (2014), pp. 64-79. p. 69.

${ }^{115}$ Lyons, P. (2015b). Kapitola 25: Je náboženství v České republice mrtvé? In P. Lyons, R. Kindlerová eds., 47 odstínu české společnosti (pp. 155-159). Praha: Sociologický ústav AV ČR.

${ }^{116}$ Laudátová, M. - Vido, R. (2010). Současná česká religiozita v generační perspektivě. Sociální Studia, 7(4), pp. 37-61, p. 52.

117 Vlachová, K., ed. (2015). Národní identity a identifikace: Ceská republika - Visegrádská ćtyrkea - Evropská unie. Praha: Slon, p. 141. 


\section{- Other artefacts of a symbolic nature relating to Czech national identity}

Not all artefacts that are historically linked to Czech national identity are at the same time classified in a material cultural heritage area. Artefacts that are linked in the minds of the Czechs or in media discourse to the Czech Republic are therefore designated for a separate subcategory, which is intended for further fulfilment in the context of follow-up research investigations. We can include here things like the Trabant and the Panel House, onion-patterned dishes, Czech grenade, etc. ${ }^{118}$ Let us note that these are often things from the socialism era, which are now part of the phenomenon of "retro." Phenomenon retro as part of a fashion wave, and perhaps also as kind of nostalgia, place these objects in new contexts of usage and symbolism.

\section{Conclusion}

In its theoretical anchoring, the study was predominantly based on the current modernist paradigm (Gellner), with which the study identifies in terms of the concept of national identity as a modern phenomenon linked to the emergence of nationalism and a on the ethnosymbolist paradigm (Hroch, Smith), which offers a stimulating space for understanding the national identity as a group identity constructed and existing in a specific historical-cultural context, which is associated with the continuous generational transfer of elements around whose national identity is constructed and reconstructed.

The aim of the study was to create a categorization scheme of elements constructing the Czech national identity. The resulting coding key allows categorizing the elements involved in the process of construction and formation of the Czech national identity connected with the idea of what it means to be Czech. By studying and analysing literature and related surveys on this topic, a coding key was created. Coding key based on five main categories. Coding key based on five main categories. They are category Czechs and their roots; Czechs and their shared memories of important historical events and personalities; Czechs and their characteristic cultural features; Czechs and national territory, National state; Other elements and sites of memory related to the Czech national identity. All of these categories contain other subcategories that further develop them they illustrate the national identity they contain, constructing and shaping elements.

The aim of the coding key (presented categorization scheme of the elements constructing Czech national identity), among other things, was to help anchor and a typical image of Czech national identity that would correspond to the current social discourse. This ideal-typical model and list of elements constructing Czech national identity is useful for realizing how the Czech national identity within the

\footnotetext{
${ }^{118}$ Havlůjová, H. - Najbert, J. et al. (2014). Pamèt a projektové vyučování v dějepise. Praha: Ústav
} pro studium totalitních režimů. p. 18. 
Czech social discourse looks and therefore what most Czechs imagine under it. But because it is ideally-typical model, it cannot be assumed that this form of Czech national identity appears exactly in this form for all Czechs. It is also clear that the coding key thus created will not be static in time, but its form may change over time as it changes to change the form of social life and social reality. Still, this model is for the next social science research is beneficial as it allows it to be used in other researches that can for example, to find out to what extent the concept of the Czech identity of selected respondents to this model approaching or moving away. Potentially, the key can always be supplemented with additional elements.

An interesting finding is the fact that the elements involved in the process of construction of the Czech national identity take on a relatively traditional form. In concept of Czech national identity still dominates the reference to (sometimes supposedly) a common national past (often it is "pre-national" ethnic history of the Slavs) and the events that took place there. These events are interpreted in the context of today's time in a specific way (such as the First Republic), or are full of contradictions (Hussiteism). They can be associated with the idea of the Golden Age (the reign of Charles IV.) or with the memory of the period of decline (Munich Agreement), which are often associated with specific places that have also become symbols of the Czech nation and its historical experience (Charles University, Wenceslas Square, Lidice, etc.). In addition to places created by people, typical elements of the Czech landscape and related customs, such as mushrooming and spending time at holiday cottages, are also involved in the creation of Czech identity. Important elements of Czech national identities are important Czech personalities who are perceived by people as people of national importance (Charles IV., Masaryk, famous artists, inventors, but also fictional characters such as Švejk or Cimrman, etc.). An important element on which Czech identity has been based since National Revival is Czech language that helps shape the identity of our own group "we" - people speaking Czech language. The role of the Czech state, whose territories and borders help to categorize one's own nation as distinct from other nations, also plays a similar role today. The Czech state is also associated with the state symbols that participate in the commemoration historical continuity of the country and its importance. Significant elements involved in process of construction of Czech national identity are cultural features and characteristic which are by people perceived as typical for their nation. Often these are constructed autostereotypes, such as "golden Czech hands", which testify to the Czech diligence and skill. These conceptions of Czechism often once again take a traditional form because they are connected with the ideas that of the Czechs were constructed and reconstructed by national revivalists during the 19th century. Important elements are also specific national values and attitudes (including the degree of patriotism), but also Czech cultural heritage and national traditions (verbal folklore, crafts, customs and traditions). Among others groups of elements constructing Czech national identity can then form a specific relationship of Czechs to religion. It turns out that the relationship of Czechs to religion is not as simple as it is often reported by the media, which present the Czechs as a nation of "non-believers". 